\title{
Erratum to: Oral and Maxillofacial Sclerosing Epithelioid Fibrosarcoma: Report of Five Cases
}

\author{
Gretchen S. Folk • Stephen B. Williams • \\ Robert B. Foss · Julie C. Fanburg-Smith
}

Published online: 15 December 2012

(C) Springer Science+Business Media New York 2012

Erratum to: Head and Neck Pathol (2007) 1:13-20

DOI 10.1007/s12105-007-0002-9

The original version of this article unfortunately contained a mistake. The spelling of the word "fibrosarcoma" was incorrect in the PDF version of this article. The corrected title is given above.

The online version of the original article can be found under doi:10.1007/s12105-007-0002-9.

G. S. Folk $(\square)$

Department of Pathology, Naval Medical Center San Diego, San Diego, CA, USA

e-mail: gretchen.folk@med.navy.mil; gretchenfolk@yahoo.com

S. B. Williams · R. B. Foss

Oral and Maxillofacial Pathology Department, Armed Forces

Institute of Pathology, Washington, DC, USA

J. C. Fanburg-Smith

Orthopaedic and Soft Tissue Pathology Department, Armed

Forces Institute of Pathology, Washington, DC, USA 